\title{
The Empirical Analysis of State-Owned Enterprises Performance and Ownership Structure: Based on the Panel Data of State-Owned Enterprises in Sichuan
}

\author{
Xuefeng Du, Yixiang Tian, Gaoxun Zhang, Honglei Zhang \\ School of Economics and Management, University of Electronic Science and Technology of China, Chengdu, \\ China \\ Email: 64922479@qq.com
}

Received August 2014

\begin{abstract}
In this paper, we used Super-efficient DEA methodology and panel data analysis methods to analysis of the relationship between the performance of state-owned enterprises of Sichan and its shareholding structure. The results showed that: there is no significant correlation between the ownership concentration and corporate performance; there exists significant negative correlation between the proportion of state-owned shares and corporate performance; there is no significant correlation between the proportion of corporate shares and corporate performance. Thus, that moderate control the proportion of state-owned shares will be benefit to the state-owned enterprises of Sichuan.
\end{abstract}

\section{Keywords}

State-Owned Enterprise Performance, Super-Efficient DEA, Panel Data Model, Ownership Structure

\section{Introduction}

As the backbone of the national economy, State-owned enterprises play a crucial role for China's economic and social development. The state-owned enterprise of Sichuan plays an important role in the process of developing the western region. Analysis of the problems of state-owned enterprises of Sichuan and optimize performance management of state-owned enterprises will be of great significance to local economic development in Sichuan. In this paper, we used Super-efficient DEA methodology and panel data analysis methods to analysis of the relationship between the performance of state-owned enterprises of Sichan and its shareholding structure. The result will provide a reference to optimize the corporate structure for government decision-making departments and business managers

The relation between ownership structure and corporate performance has been a hotspot of financial academic 
research. As state-owned shareholding structure reflects the company risk taking and mechanism of profit allocation. There are closely related relationship between ownership structure and corporate value. But so far, there is no clear consistent result between ownership structure and firm performance in historical documents. Demsetz and Lehn [1] studied 511 large U.S. companies, found that there is not relevant between ownership concentration and firm performance (ROE). However, the research of McConnel and Servaes [2] showed that there was a non-linear relationship between ownership structure and corporate performance. Through analysis of existing research literature, we found that there were no unified empirical results between ownership structure and firm performance. The main reason for this result was that the measures of corporate performance were different. Corporate performance indicators using different study on the same issue may get different results. Therefore, a more scientific performance measures will be essential conclusions of the study. In this paper we use the DEA method to measure corporate performance, hoping to get closer to the objective facts of the conclusions.

\section{Data Sources and Research Ideas}

\subsection{Data Sources}

This data come from CSMAR database, we had chosen annual financial data of the state-owned enterprise in Sichuan from 2006 to 2009. In order to maintain a consistent time, we excluded the enterprise that miss data, and eventually collected 48 samples.

\subsection{Research Ideas}

\subsubsection{Index Selection}

The estimation methods of corporate performance are many. In this paper, the internationally popular business performance evaluation method-DEA method was used. DEA method is one of many methods of enterprise performance evaluation that is widely accepted. For further information about the DEA method, see Banker, Charnes and Cooper [3], Chames, Cooper and Rhodes [4], Pekka and Luptacik [5], Andersen and Petersen [6] etc. When using DEA method, you need to set the input and output indicators. In this paper, we select asset-liability ratio, total assets and employee benefits payable as input indicators, and select total revenue, gross profit and net profit, etc., as output indicator.

Ownership concentration is the common indicators of concentration of corporate equity. In this paper, the Herfindahl index is used to measure the degree of ownership concentration, the $\mathrm{j}$-th enterprise ownership concentration is expressed as follows:

$$
\operatorname{Herfindahl}_{j}=\sum_{i=1}^{I} s_{i j}^{2}
$$

where, $s_{i j}$ means the share what i-th equity owners in the j-th firm has. The higher Herfindahl index shows that the more concentrated corporate equity. Hou and Robinson [7] found that the Herfindahl index which was calculated by the company's total assets, book value and net sales were highly consistent (correlation coefficient above 0.9 ). Therefore, in this paper, we only used the company's total assets to compute industry concentration index. In addition to ownership concentration, the proportion of state enterprises, the proportion of corporate shares and the proportion of outstanding shares are closely related with corporate performance. This article will examine the relation between these factors and firm performance. According to the research of Morck and Maconnell, the gearing ratio (DAR), net profit growth (GROW) and company size (SIZE) impact on corporate performance. In this paper, we used the three indicators as control variables. We used the company's net profit growth as the company's growth targets, and used the natural logarithm of the total revenue as the scale of indicators.

\subsubsection{Research Ideas}

First, use super-efficient DEA method to calculate the value of enterprise performance;

Second, examine the relationship between ownership concentration and firm performance. Use panel data regression model to estimate and test the relationship between ownership concentration and firm performance. Specific regression model is:

$$
D E A_{i t}=a_{i}+\beta_{i} H_{i t}+\lambda_{1} G R O W_{i t}+\lambda_{2} S_{Z I E}+\lambda_{i t} D A R_{i t}+\varepsilon_{i t}
$$


where $D E A_{i t}$ is enterprise performance calculated based on DEA, $H_{i t}, G R O W_{i t}, S I Z E_{i t}$ and $D A R_{i t}$ represent owner ship concentration, net profit growth, company size and the Asset-liability ratio.

Finally, we present empirical that was about the relationship between corporate performance and equity constitute. Regression equation was the Equation (2), that is

$$
D E A_{i t}=a_{i}+\lambda_{1} G R O W_{i t}+\lambda_{2} S I Z E_{i t}+\lambda_{3} D A R_{i t}+F_{i t}+\varepsilon_{i t}
$$

where $F_{i t}$ represents the proportion of state-owned shares and legal person shares

\section{Empirical Analysis}

\subsection{State-Owned Enterprise Performance}

Figure 1 shows the overall performance of state-owned enterprises of Sichuan from 2006 to 2009. Vertical axis is the average performance of the state-owned enterprises. Figure 1 shows that: by 2008, the average performance of state-owned enterprises was rising. However, due to the global economic crisis of 2008 and the Sichuan earthquake, average performance of the state-owned enterprises of Sichuan was severely affected, began a downward trend.

\subsection{Corporate Performance and Ownership Concentration}

In order to investigate the relationship between the corporate performance and ownership structure, we conducted a regression analysis of company performance and ownership concentration. The results are given in Table 1:

Table 1 shows the regression results of relationship between corporate performance and ownership concentration and other enterprise characteristic variables. Regression -5 Shows that the coefficient of ownership concentration is not significant, the remaining coefficients are significant ( 0.01 significance level), and the coefficients signs of explanatory variables in the regression equation of different are consistent. This shows that the regression model is robust. Table 1 report that the coefficient of ownership concentration is -0.2006 in the regression -5 , and is not significant ( 0.01 significance level). Therefore, we cannot explain that there exists a certain negative correlation between ownership concentration and firm performance, that is to say that ownership concentration will not affect the company's performance.

\subsection{Corporate Performance and the Ownership Structure}

Several former shareholders of state-owned enterprises of Sichuan are most of the state and legal person shares, and individual shareholders are only a very small part, therefore, this section only analyzed the relationship between the firm performance and the proportion of state-owned shares and legal person shares. In order to investigate the relationship between corporate performance and ownership structure we analysis the relationship among the enterprise performance, the proportion of state-owned shares (F1), the proportion of corporate shares (F2), and other industry characteristics variables. Table 2 gives regression results

Table 2 show that there is no evidence to support that there existed correlation between the enterprise legal person shares and firm performance.

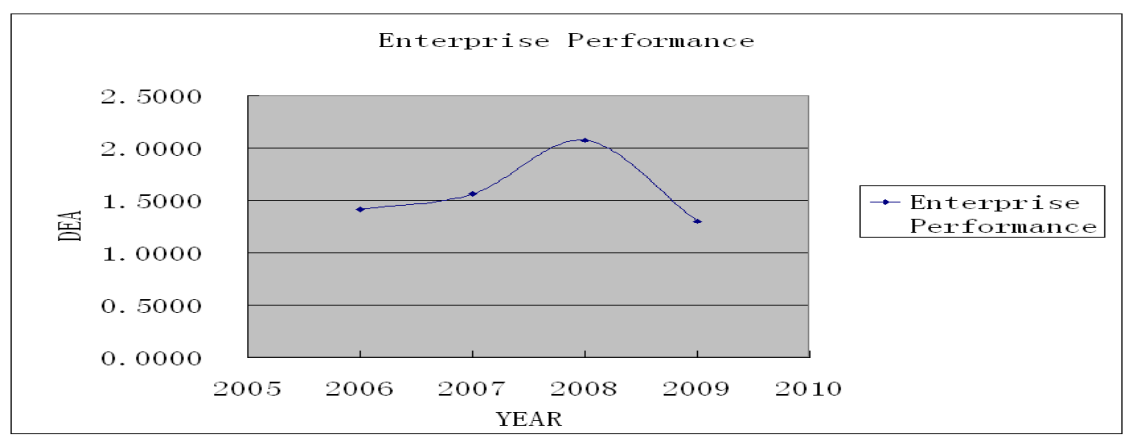

Figure 1. State-owned enterprise performance of Sichuan from 2006 to 2009. 
Table 1. The relationship between company performance and ownership concentration.

\begin{tabular}{|c|c|c|c|c|c|c|}
\hline Dependent variable & Intercept & $\mathrm{H}$ & DAR & GROW & SIZE & Adj-R2 \\
\hline \multirow[t]{2}{*}{ Regression-1 } & $1.0554^{* *}$ & -0.2006 & & & & 0.1703 \\
\hline & 6.2535 & -0.2886 & & & & \\
\hline \multirow[t]{2}{*}{ Regression-2 } & $1.2485^{* *}$ & & $-0.3264^{* *}$ & & & 0.1609 \\
\hline & 6.0344 & & -2.3010 & & & \\
\hline \multirow[t]{2}{*}{ Regression-3 } & $1.0791^{* *}$ & & & $0.0004^{* *}$ & & 0.1187 \\
\hline & 7.1598 & & & -2.1096 & & \\
\hline \multirow[t]{2}{*}{ Regression-4 } & $-10.3696^{* *}$ & & & & $1.3094^{* *}$ & 0.3410 \\
\hline & -5.4921 & & & & 6.2871 & \\
\hline \multirow[t]{2}{*}{ Regression-5 } & $-10.6189^{* *}$ & -0.1391 & $-0.5229^{* *}$ & $0.0014^{* *}$ & $1.3661^{* *}$ & 0.3485 \\
\hline & -5.3359 & -0.1328 & -1.1951 & 3.0960 & 6.4525 & \\
\hline
\end{tabular}

Note: 1) “"” indicates significant at the 0.05 level, “**” indicates significance at the 0.01 level; 2) T-value of the parameter estimates in parentheses; 3 ) Select mixed models to estimate parameters.

Table 2. Corporate performance and ownership structure.

\begin{tabular}{cccccccc}
\hline $\begin{array}{c}\text { Dependent } \\
\text { variable }\end{array}$ & Intercept & F1 & F2 & DAR & GROW & SIZE & Adj-R2 \\
\hline Regression-1 & $-10.2123^{* *}$ & $-0.0068^{* *}$ & & -0.3387 & $0.0017^{* *}$ & $1.3126^{* *}$ & 0.3394 \\
& -4.0797 & -4.3452 & & -0.5311 & 7.2392 & 4.5248 \\
Regression-2 & $-10.6669^{* *}$ & & 0.0023 & -0.4745 & $0.0014^{* *}$ & $1.3584^{* *}$ & 0.3573 \\
& -4.4136 & & 0.3125 & -0.7458 & 6.5862 & 4.9037 & 0.3642 \\
Regression-3 & $-10.3898^{* *}$ & $-0.0057^{* *}$ & 0.0021 & -0.3725 & $0.0018^{* *}$ & $1.3255^{* *}$ & 0.4525 \\
\hline
\end{tabular}

Note: 1) “"” indicates significant at the 0.05 level, “"*” indicates significance at the 0.01 level; 2) T-value of the parameter estimates in parentheses; 3 ) $\mathrm{F} 1$ and $\mathrm{F} 2$ respectively represent the proportion of state-owned shares and legal person shares.

\section{Conclusions and Recommendations}

In this paper, we conducted an empirical analysis to the relationship between the performance of state-owned enterprises of Sichuan and shareholding structure. The main conclusions are following:

First, there is no significant correlation between the ownership concentration and the performance of stateowned enterprise of Sichuan; there exists significant negative correlation between the proportion of state-owned shares and corporate performance; there is no significant correlation between the the proportion of corporate shares and corporate performance. Thus, that moderate control the proportion of state-owned shares will be benefit to the state-owned enterprises of Sichuan. Management departments of the company should further optimize the ownership structure.

Secondly, using the super-efficient DEA method to portray corporate performance and study the relationship between enterprise performance and ownership structure, we obtained the similar conclusions to Song and Zhu, but inconsistencies to Li. This showed that in the research of enterprise performance, how to determine the performance indicators was essential. To ensure the objectivity of research findings, researchers should use the metrics indicators that can better reflect the objective situation of corporate performance.

\section{References}

[1] Harold, D., Kenneth, L., et al. (198) The Structure of Corporate Ownership: Causes and Consequences. The Journal of 
Political Economy, 6, 1155-1184.

[2] McConnell, J. and Servaes, H. (1995) Additional Evidence on Equity Ownership and Corporate Value. Journal of Financial Economics, 27, 595-612. http://dx.doi.org/10.1016/0304-405X(90)90069-C

[3] Banker, R.D., Charnes, A. and Cooper, W.W. (1984) Some Models for Estimating Technical and Scale Inefficiencies in Date Envelopment Analysis. Management Science, 66-72.

[4] Charnes, A., Cooper, W.W. and Rhodes, E. (1979) Short Communication: Measuring Efficiency of Decision Making Units. European Journal Operational Research, 3, 339. http://dx.doi.org/10.1016/0377-2217(79)90229-7

[5] Pekka, J.K. and Luptacik, M. (2004) Eco-Efficiency Analysis of Power Plants: An Extension of Data Envelopment Analysis. European Journal of Operational Research, 154, 437-446. http://dx.doi.org/10.1016/S0377-2217(03)00180-2

[6] Andersen, P. and Petersen, N.C. (1993) A Procedure for Ranking Efficient Units in Data Envelopment Analysis. Management Science, 39, 1261-1264. http://dx.doi.org/10.1287/mnsc.39.10.1261

[7] Hou, K. and Robinson, D.T. (2006) Industry Concentration and Average Stock Returns. Journal of Finance, 61, $1927-$ 1956. http://dx.doi.org/10.1111/j.1540-6261.2006.00893.x 